\title{
ANALISIS PERBANDINGAN FITOPLANKTON DAN ZOOPLANKTON SERTA TSI (TROPHIC SAPROBIC INDEX) PADA PERAIRAN TAMBAK DI KAMPUNG TAMBAK LOROK SEMARANG
}

\author{
The Analysis of Comparison Phytoplankton and Zooplankton and TSI (Trophic Saprobic Index) on Waters of \\ Ponds in Tambak Lorok Village Semarang
}

\author{
Achmad Fuad Suwandana, Pujiono Wahyu Purnomo*), Siti Rudiyanti \\ Program Studi Manajemen Sumberdaya Perairan, Departemen Sumberdaya Akuatik \\ Fakultas Perikanan dan Ilmu Kelautan, Universitas Diponegoro Jl. Prof. Soedarto, \\ SH, Tembalang, Semarang, Jawa Tengah - 50275, Telp/Fax. +6224 7474698 \\ Email :achmadfuad888@gmail.com
}

\begin{abstract}
ABSTRAK
Lokasi Tambak Lorok dekat dengan jalan raya, pemukiman penduduk serta pabrik-pabrik besar sehingga berpotensi menampung bahan pencemarnya. Bahan-bahan pencemar tersebut akan mengganggu keseimbangan organisme di dalam tambak salah satunya adalah plankton. Tujuan dari penelitian ini adalah untuk mengetahui kelimpahan fitoplankton dan zooplankton, mengetahui perbandingan fitoplankton dan zooplankton, dan mengetahui status saprobitas. Penelitian ini menggunakan metode deskriptif yang dilaksanakan pada bulan September 2017 di perairan tambak di Kampung Tambak Lorok Semarang. Sampling dilakukan dengan menggunakan purposive sampling pada 4 stasiun dengan masing-masing stasiun 3 titik. Variabel yang diukur adalah kelimpahan fitoplankton, kelimpahan zooplankton, dan nilai saprobitas. Hasil penelitian menunjukkan kelimpahan fitoplankton berkisar antara 47-154 ind/l dan kelimpahan zooplankton berkisar antara 0-9 ind/l. Perbandingan fitoplankton dan zooplankton berkisar antara 7:1 sampai 47:0. Nilai SI (Saprobik Indeks) berkisar antara 1,28-1,33 dan nilai TSI (Tropik Saprobik Indeks) berkisar antara 1,89-2,50. Berdasarkan nilai SI dan TSI dapat diketahui bahwa kondisi tambak di Kampung Tambak Lorok Semarang termasuk ke dalam perairan Oligosaprobik atau perairan belum tercemar sampai tercemar ringan dan sebagian besar dalam status $\beta$ Mesosaprobik atau tercemar ringan sampai sedang.
\end{abstract}

Kata kunci: Fitoplankton; Zooplankton; Saprobitas; Tambak Lorok; Tambak

\begin{abstract}
Tambak Lorok Village is located in residential areas-densely populated, not far from highway and large factories which potentially accomodating pollution. They, the pollutants disrupt the balance of organismd in the pond, one of them plankton are going to study is plankton. Purpose of this research is to know the abundance of phytoplankton and zooplankton, the comparison of phytoplankton and zooplankton as well as the status of saprobity. This research was carried out on September 2017 in the pond waters at Tambak Lorok Semarang Village by using descriptive method. Sampling was applied by using purposive at 4 station, each station using 3 point. Measured variables were phytoplankton abundance, zooplankton abundance, and saprobity value. The results showed that phytoplankton abundance ranged between 47-154 ind/l, while zooplankton abundance betweem 0-9 ind/l. Comparison of phytoplankton and zooplankton ranged from 7:1 to 47:0. The SI (Sabrobik Index) value ranged from 1,28-1,33 and the TSI (Tropic Saprobik Index) value ranged from 1,89-2,50. Based on SI dan TSI values mentioned above the condition of ponds in Tambak Lorok Village is classified as Oligosaprobik or uncured waters to minor contaminated and mostly in $\beta$-Mesosaprobik status or mild to moderate contamination.
\end{abstract}

Keywords: Phytoplankton; Zooplankton; Saprobity; Tambak Lorok; Pond

*) Penulis Penanggungjawab

\section{PENDAHULUAN}

Pembudidayaan ikan adalah kegiatan untuk memelihara, membesarkan dan/atau membiakkan ikan serta memanen hasilnya dalam lingkungan yang terkontrol (UU No. 31/2004). Kegiatan-kegiatan yang umum termasuk di dalamnya adalah budidaya ikan, budidaya udang, budidaya tiram dan budidaya rumput laut (alga). Di Indonesia, budidaya perairan dilakukan melalui berbagai sarana. Kegiatan budidaya yang paling umum dilakukan di kolam/empang, tambak, tangki, karamba, serta jaring apung. Kegiatan budidaya tambak merupakan pemanfaatan wilayah pesisir sebagai lahan budidaya sehingga dapat meningkatkan jumlah lapangan kerja untuk masyarakat dan perolehan devisa (Mustafa et al., 2010). Beberapa komoditas yang biasa dibudidayakan adalah udang, kepiting, bandeng, nila dan rumput laut. masing-masing komoditas biasa dibudidayakan pada petakan tambak dengan satu 
jenis komoditas (monokultur) dan juga memanfaatkan satu petakan tambak untuk beberapa komoditas yang didiversifikasi dengan komoditas lain (polikultur).

Plankton adalah organisme renik yang hidup melayang-layang diperairan. Terdapat dua kelompok besar plankton, yaitu fitoplankton dan zooplankton. Fitoplankton adalah plankton yang dapat melakukan fotosintesis dan merupakan produsen primer di perairan, dan zooplankton adalah hewan air yang melayang-layang di perairan (Faiqoh, 2015). Fitoplankton adalah tumbuh-tumbuhan air yang berukuran sangat kecil dari sejumlah kelas yang berbeda. Mereka mempunyai peranan yang sama pentingnya baik di sistem pelagik maupun seperti yang diperankan juga oleh tumbuh-tumbuhan hijau yang lebih tinggi tingkatnya di ekosistem darat. Mereka adalah produsen utama (primary producer) zat-zat organik (Hutabarat dan Evans, 2012).

Menurut Anggoro (1988), Saprobitas perairan adalah keadaan kualitas air yang diakibatkan adanya penambahan bahan organik dalam suatu perairan yang biasanya indikatornya adalah jumlah dan susunan spesies dari organisme di dalam perairan tersebut. Menurut Parsoone dan De pauw (1983) dalam Utomo (2013), bahwa tingkat saprobik akan menunjukkan derajat pencemaran yang terjadi di dalam perairan dan akan diwujudkan oleh banyaknya jasad renik indikator pencemaran.

Tujuan dari penelitian ini adalah sebagai berikut:

1. Mengetahui kelimpahan fitoplankton dan zooplankton;

2. Mengetahui perbandingan fitoplankton dan zooplankton;

3. Mengetahui status saprobitas.

\section{MATERI DAN METODE PENELITIAN}

\section{A. Materi Penelitian}

Materi yang digunakan pada penelitian ini adalah sampel air di perairan tambak di Tambak Lorok. Alat

yang digunakan untuk sampling lapangan adalah plankton net, botol sampel, DO meter, pH paper, refraktometer, pipet tetes, termometer, secchi disk, pipet tetes dan kertas label. Alat yang digunakan untuk identifikasi plankton di laboratorium adalah mikroskop dan sedgwick rafter. Bahan yang digunakan adalah sampel air yang didapat dari perairan tambak di Tambak Lorok dan formalin 4\% untuk pengawetan sampel.

\section{B. Metode Penelitian}

Metode yang digunakan dalam penelitian ini adalah metode desktriptif. Notoatmodjo (2002), metode deskriptif merupakan suatu metode penelitian yang dilakukan dengan tujuan sama untuk membuat gambaran atau deskripsi tentang suatu keadaan secara objektif.

Pengambilan sampel menggunakan metode purposive sampling. Metode ini memiliki pengertian yaitu sampel diambil dengan maksud atau tujuan tertentu oleh peneliti (Zulnaidi, 2007). Pengambilan sampel dilakukan dengan mengambil 50 liter air tambak dengan menggunakan ember 10 liter dan disaring menggunakan plankton net no 25. Lokasi sampling pada penelitian dilakukan pada 4 tambak di perairan tambak di Tambak Lorok Semarang dengan masing-masing tambak 3 titik dengan 1 kali pengulangan.

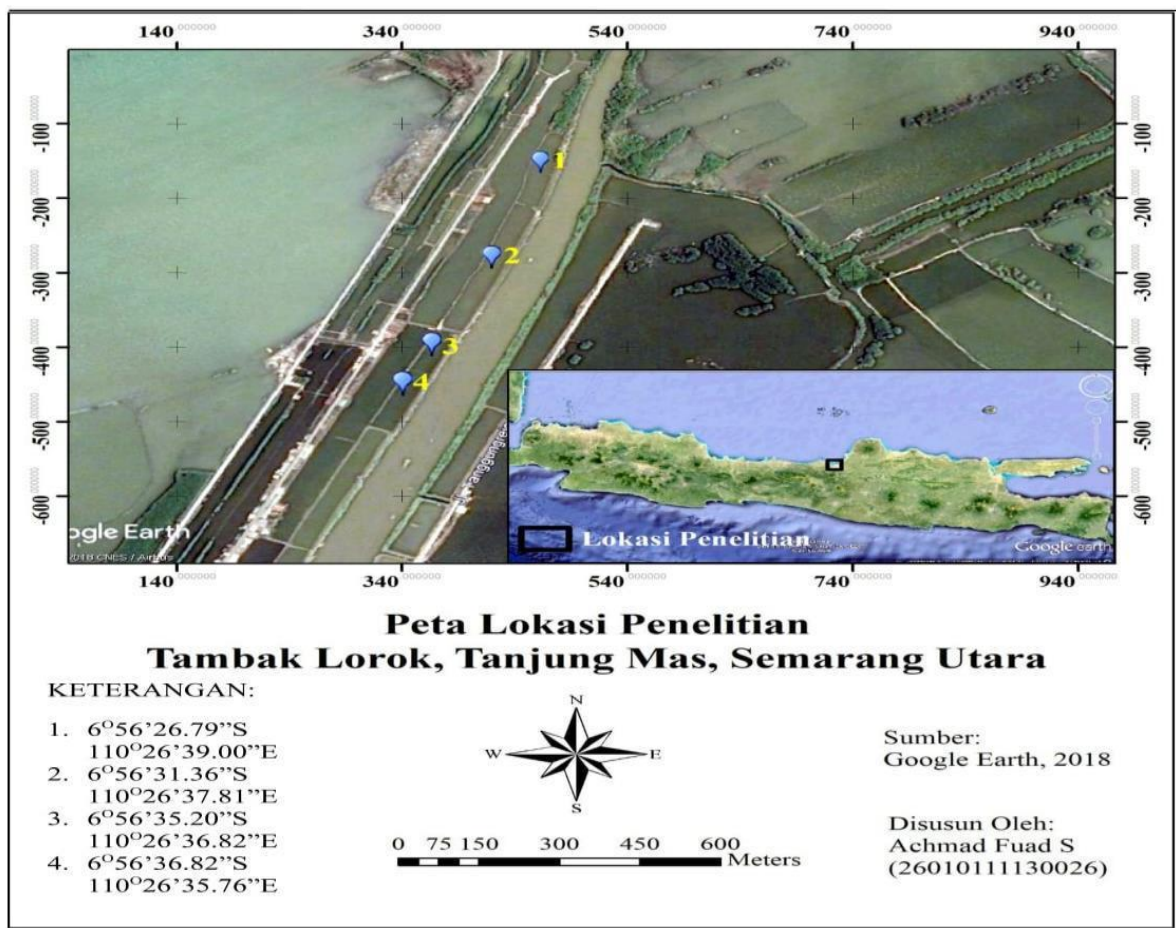

Gambar 1. Lokasi Penelitian 


\section{Analisis Data}

Identifikasi organisme plankton dilakukan dengan menggunakan mikroskop. Pengamatan dan perhitungan organisme dilakukan dengan bantuan Sedgwick rafter. Pengidentifikasian plankton dilakukan dengan menggunakan buku identifikasi Sachlan (1982) dan Davis (1955). Setelah dilakukan identifikasi jenis-jenis plankton, dilakukan perhitungan untuk mencari nilai kelimpahan fitoplankton dan zooplankton, Indeks Keanekaragaman, Indeks Kemerataan, Indeks Dominasi, perbandingan fitoplankton dan zooplankton, dan saprobitas berupa SI dan TSI.

\section{Kelimpahan Fitoplankton}

Perhitungan kelimpahan plankton dilakukan menurut APHA (1980) dalam Kartika et al. (2015), dengan menggunakan rumus sebagai berikut:

$$
\mathrm{N}=\underset{\mathrm{vc}}{=}
$$

Keterangan:

$\mathrm{N}=$ Kelimpahan plankton (ind/l)

ns = Jumlah plankton pada Sedgwick Rafter Counting Cell (ind)

$\mathrm{va}=$ Volume air terkonsentrasi dalam contoh $(\mathrm{ml})$

vs $=$ Volume air dalam preparat Sedgwick Rafter Counting Cell (ml)

$\mathrm{vc}=$ Volume air contoh yang disaring $(\mathrm{L})$

\section{Indeks Keanekaragaman}

Keanekaragaman jenis dihitung menggunakan Indeks Keanekaragaman Shanon-Wiener (Suprobo et al., 2013), yaitu:

$$
H^{\prime}=-\sum_{i=1}^{n} \overline{n i}_{{ }^{N} \times \ln ^{n_{N}}}-
$$

Keterangan:

H' = Indeks Keanekaragaman

$\mathrm{n}=$ Jumlah yang menyusun komunitas

ni $=$ Jumlah individu jenis ke-i

$\mathrm{N}=$ Jumlah individu total

Kriteria penilaian berdasarkan keanekaragaman jenis adalah:

$$
\begin{array}{ll}
\mathrm{H}^{\prime}<1 & : \text { Keanekaragaman rendah } \\
1<\mathrm{H}^{\prime}<3 & : \text { Keanekaragaman sedang } \\
\mathrm{H}^{\prime}>3 & : \text { Keanekaragaman tinggi }
\end{array}
$$

\section{Indeks Keseragaman}

Indeks ini untuk menunjukkan pola sebaran biota, yaitu merata atau tidak. Jika nilai indeks keseragaman realif tinggi, maka keberadaan setiap jenis biota di perairan dalam kondisi merata. Analisa indeks keseragaman fitoplankton menurut Odum (1971) dalam Suprobo et al. (2013) menggunakan rumus:

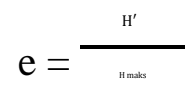

keterangan:

$$
\begin{array}{ll}
\mathrm{e} & =\text { Indeks keanekaragaman } \\
\mathrm{H} \text { maks } & =\ln \mathrm{S}(\mathrm{S} \text { adalah jumlah genera }) \\
\mathrm{H}^{\prime} & =\text { Indeks keanekaragaman }
\end{array}
$$

Kriteria indeks:
$\mathrm{E} \leq 0$
: Keseragaman kecil, komunitas tertekan
$0.5 \leq \mathrm{E} \leq 0.1$
: Keseragaman sedang, komunitas labil
E $>0.5$
: Keseragaman tinggi, komunitas stabil 


\section{Indeks Dominasi}

Menurut Odum (1971) dalam Suprobo et al. (2013), untuk mengetahui adanya dominasi tertentu di perairan dapat digunakan indeks dominasi dengan persamaan berikut:

$\mathrm{C}=\sum\left(\mathrm{ni}_{\mathrm{n}}\right)^{2}$

Keterangan:

$\mathrm{C}=$ Indeks dominasi

ni $=$ Jumlah individu tiap spesies

$\mathrm{N}=$ Total individu

Kriteria indeks:

$0 \leq \mathrm{C} \leq 0.30 \quad$ : Dominasi rendah

$0.30 \leq \mathrm{C} \leq 0.60 \quad$ : Dominasi sedang

$0.60 \mathrm{C} \leq 1.00 \quad$ : Dominasi tinggi

\section{Saprobik Indeks (SI) dan Tropik Saprobik Indeks (TSI)}

Untuk menghitung saprobitas perairan digunakan analisis TROSAP yang nilainya ditentukan dari formulasi Persone dan De Pauw (1983) dalam Anggoro (1988):

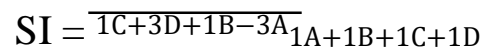

Keterangan:

A = Jumlah Spesies Organisme Polisaprobik

$\mathrm{B}=$ Jumlah Spesies Organisme $\alpha$-Mesosaprobik

$\mathrm{C}=$ Jumlah Spesies Organisme $\beta$-Mesosaprobik

$\mathrm{D}=$ Jumlah Spesies Organisme Oligosaprobik

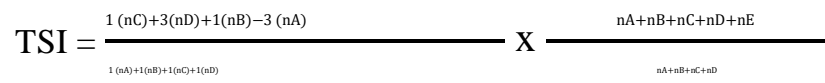

Keterangan:

$\mathrm{N} \quad=$ Jumlah individu organisme pada setiap kelompok saprobitas

$\mathrm{nA}=$ Jumlah individu penyusun kelompok Polisaprobik

$\mathrm{nB} \quad=$ Jumlah individu penyusun kelompok $\alpha$-Mesosaprobik

$\mathrm{nC}=$ Jumlah individu penyusun kelompok $\beta$-Mesosaprobik

$\mathrm{nD} \quad=$ Jumlah individu penyusun kelompok Oligosaprobik

$\mathrm{nE} \quad=$ Jumlah individu penyusun selain A, B, C dan D

Tingkat saprobitas perairan ditentukan berdasarkan nilai Saprobik Indeks (SI), Tropik Saprobik Indeks (TSI) menurut Lee et al. (1987) dan Knobs (1978) dalam Utomo (2013) dapat dilihat pada Tabel 1.

Tabel 1. Tingkat Saprobitas Perairan.

\begin{tabular}{lll}
\hline Nilai SI/TSI & Tingkat Saprobitas & Keterangan \\
\hline$<-3 \mathrm{~s} / \mathrm{d}-2$ & Polisaprobik & Pencemaran berat \\
$<-2 \mathrm{~s} / \mathrm{d} 0,5$ & $\alpha$-Mesosaprobik & Pencemaran sedang sampai berat \\
$0,5 \mathrm{~s} / \mathrm{d} 1,5$ & $\beta$-Mesosaprobik & Pencemaran ringan sampai sedang \\
\hline $1,5 \mathrm{~s} / \mathrm{d} 2,0$ & Oligosaprobik & Pencemaran ringan atau belum tercemar \\
\hline
\end{tabular}

\section{HASIL DAN PEMBAHASAN}

\section{A. Hasil}

Gambaran Umum Lokasi Penelitian

Berdasarkan hasil penelitian, pengambilan sampel dilakukan di 4 tambak dengan masing-masing 3 titik. Keempat tambak tersebut termasuk ke dalam tambak tradisional. Tambak-tambak tersebut menggunakan tanah dan letaknya tepat di sebelah muara banjir kanal. Tambak 1 dan 2 memiliki ukuran yang besar memanjang, ukuran tambak 1 dan 2 memiliki panjang sekitar 70-80 m dan lebar sekitar 20-25 m, dengan warna air cokelat kehijauan dan airnya berbau agak amis. Tambak 1 dan 2 dipisahkan oleh waring, dengan 1 inlet/outlet yang 
berada di tambak 1. Terdapat beberapa mangrove di sekitar tambak 1 dan disekitar tambak banyak terdapat sampah. Tambak 3 dan tambak 4 memiliki ukuran lebih kecil, memiliki ukuran panjang sekitar 40-50 m dan lebar 20-25 m letaknya berdekatan dan dipisahkan oleh jalan pematang. Warna air dari tambak 3 dan tambak 4 berwarna hijau kecokelatan dan berbau agak amis. Banyak terlihat kepiting di sekitar pinggiran tambak 3 dan 4 . Tambak 3 memiliki 1 inlet/outlet sedangkan tambak 4 tidak memiliki inlet/outlet. Banyak terdapat sampah di sekitar jalan dekat tambak. Jika melihat kondisi sekitar tambak, proses pergantian air di tambak mengandalkan pasang surut air laut atau melalui inlet/outlet tambak yang mengarah langsung ke muara banjir kanal, karena tidak adanya tandon air di sekitar tambak yang biasanya befungsi untuk mengganti air tambak.

\section{Kondisi Kualitas Perairan}

Tabel hasil nilai rata-rata pengukuran parameter fisika dan kimia terdapat pada Tabel 2.

Tabel 2. Hasil Rata-rata Pengukuran Paramater Fisika Kimia.

\begin{tabular}{cccccccccc}
\hline \multicolumn{10}{c}{ Rata-rata } \\
\hline Tambak & $\begin{array}{c}\text { Suhu air } \\
\left({ }^{\circ} \mathrm{C}\right)\end{array}$ & $\begin{array}{c}\text { Kedalaman } \\
(\mathrm{cm})\end{array}$ & $\begin{array}{c}\text { Kecerahan } \\
(\mathrm{cm})\end{array}$ & $\begin{array}{c}\text { Arus } \\
(\mathrm{m} / \mathrm{s})\end{array}$ & $\begin{array}{c}\text { Salinitas } \\
(\% / \mathrm{oo})\end{array}$ & $\mathrm{pH}$ & $\begin{array}{c}\text { DO } \\
(\mathrm{mg} / \mathrm{l})\end{array}$ & $\begin{array}{c}\text { Nitrit } \\
(\mathrm{mg} / \mathrm{l})\end{array}$ & $\begin{array}{c}\text { Nitrat } \\
(\mathrm{mg} / \mathrm{l})\end{array}$ \\
\hline 1 & 30 & 47.66 & 18.50 & 0 & 27.33 & 7 & 4.36 & 0.0935 & 0.7505 \\
2 & 31 & 43.33 & 21.83 & 0 & 25 & 7.66 & 4.86 & 0.0736 & 0.7135 \\
3 & 30 & 51 & 28 & 0 & 25 & 8 & 5.43 & 0.0243 & 0.6680 \\
4 & 31 & 68.33 & 28 & 0 & 25 & 8 & 5.46 & 0.0320 & 0.7373 \\
\hline
\end{tabular}

\section{Kelimpahan Fitoplankton}

Hasil analisa kelimpahan fitoplankton dapat dilihat pada Tabel 3.

Tabel 3. Kelimpahan Fitoplankton.

Kelimpahan Plankton (ind/l)

\begin{tabular}{lcccc}
\hline \multirow{2}{*}{ Fitoplankton } & Tambak 1 & Tambak 2 & Tambak 3 & Tambak 4 \\
\cline { 2 - 5 } & & & & \\
& & 5 & 15 & 6 \\
Rhizosolenia sp. & 10 & 7 & 15 & 6 \\
Navicula sp. & 17 & - & 41 & - \\
Chlorella sp. & 5 & 10 & 33 & 29 \\
Coscinodiscus sp. & 3 & 9 & 28 & 7 \\
Pleurosigma sp. & 4 & 13 & 14 & 3 \\
Synedra sp. & - & 5 & 8 & 7 \\
Oscillatoria sp. & 47 & 49 & 154 & 58 \\
\hline \multicolumn{1}{c}{ Jumlah } & & & & \\
\hline
\end{tabular}

Berdasarkan hasil analisa dari Tabel 3, kelimpahan tertinggi fitoplankton terdapat pada tambak 3 yaitu $154 \mathrm{ind} / \mathrm{l}$ dan kelimpahan terendah terdapat pada tambak 1 yaitu 47 ind/l.

\section{Kelimpahan Zooplankton}

Hasil analisa kelimpahan zooplankton dapat dilihat pada Tabel 4.

Tabel 4. Kelimpahan Zooplankton.

Kelimpahan Individu (ind/l)

$\begin{array}{llll}\text { Zooplankton } & \text { Tambak } 1 & \text { Tambak } 2 & \text { Tambak } 3\end{array}$

\begin{tabular}{lllll}
\hline Paramecium sp. & - & 7 & 6 & 7 \\
Cyclops sp. & - & - & 1 & - \\
Diaptomus sp. & - & - & 1 & 1 \\
Nauplius sp. & - & - & 1 & - \\
\hline Jumlah & - & 7 & 9 & 8 \\
\hline
\end{tabular}

Berdasarkan analisa dari Tabel 4, kelimpahan tertinggi zooplankton terdapat pada tambak 3 yaitu 9 ind/l dan kelimpahan terendah terdapat pada tambak 1 semua titik yaitu 0 ind/l. 
Indeks Keanekaragaman, Indeks Keseragaman, dan Indeks Dominasi Tabel 5.

Hasil perhitungan indeks keanekaragaman, indeks keseragaman, dan indeks dominasi dapat dilihat pada

Tabel 5. Indeks Keanekaragaman, Indeks Keseragaman dan Indeks Dominasi.

\begin{tabular}{cccc}
\hline Tambak & Keanekaragaman $\left(\mathrm{H}^{\prime}\right)$ & Keseragaman $(\mathrm{e})$ & Dominasi $(\mathrm{C})$ \\
\hline Tambak 1 & 1.622 & 0.905 & 0.227 \\
Tambak 2 & 1.893 & 0.972 & 0.160 \\
Tambak 3 & 1.987 & 0.828 & 0.161 \\
Tambak 4 & 1.715 & 0.824 & 0.244 \\
\hline
\end{tabular}

Berdasarkan Tabel 5 di atas menunjukkan bahwa nilai indeks keanekaragaman (H') tertinggi terdapat pada tambak 3 yaitu 1.987 dan nilai indeks keanekaragaman terendah terdapat pada tambak 1 yaitu 1.622. Nilai indeks keseragaman tertinggi terdapat pada tambak 2 yaitu 0.972 dan nilai indeks keseragaman terendah terdapat pada tambak 3 yaitu 0.824. Nilai indeks dominasi tertinggi terdapat pada tambak 4 yaitu 0.244 dan nilai indeks dominasi terendah terdapat pada tambak 2 yaitu 0.160 .

\section{Indeks Saprobitas}

Hasil jumlah fitoplankton dan zooplankton di Tambak Lorok Semarang yang didapatkan dari 12 titik dari 4 tambak berdasarkan golongan indeks saprobik dapat dilihat pada Tabel 6.

Tabel 6. Jumlah Fitoplankton dan Zooplankton Berdasarkan Golongan Indeks Saprobik.

\begin{tabular}{|c|c|c|c|c|}
\hline \multirow{2}{*}{ Kelompok Saprobitas } & \multicolumn{4}{|c|}{ Tambak } \\
\hline & 1 & 2 & 3 & 4 \\
\hline \multicolumn{5}{|l|}{$\alpha-$ Mesosaprobik (B) } \\
\hline Oscillatoria sp. & - & 8 & 12 & 11 \\
\hline Rhizosolenia sp. & 12 & 8 & 23 & 9 \\
\hline Navicula sp. & 15 & 11 & 22 & 9 \\
\hline Jumlah & 27 & 27 & 57 & 29 \\
\hline \multicolumn{5}{|l|}{$\beta$ - Mesosaprobik (C) } \\
\hline Pleurosigma sp. & 4 & 13 & 42 & 11 \\
\hline Nauplius sp. & - & - & 1 & - \\
\hline Paramecium sp. & - & 11 & 9 & 10 \\
\hline Jumlah & 4 & 24 & 52 & 21 \\
\hline \multicolumn{5}{|l|}{ Oligosaprobik (D) } \\
\hline Synedra sp. & 6 & 20 & 21 & 12 \\
\hline Jumlah & 6 & 20 & 21 & 12 \\
\hline \multicolumn{5}{|l|}{ Non Saprobik } \\
\hline Coscinodiscus sp. & 8 & 15 & 49 & 44 \\
\hline Chlorella sp. & 25 & - & 62 & - \\
\hline Cyclops sp. & - & - & 1 & - \\
\hline Diaptomus sp. & - & - & 1 & 1 \\
\hline Jumlah & 33 & 15 & 113 & 45 \\
\hline
\end{tabular}

Berdasarkan Tabel 6, jumlah plankton yang paling banyak ditemukan dan terdapat di semua tambak adalah Coscinodiscus sp., dari golongan non saprobik.

Hasil perhitungan SI dan TSI dapat dilihat pada Tabel 7.

Tabel 7. Nilai SI dan TSI.

\begin{tabular}{cccc}
\hline Tambak & SI & TSI & Status perairan \\
\hline Tambak 1 & 1.50 & 2.50 & $\begin{array}{c}\text { Oligosaprobik } \\
\text { Tambak 2 }\end{array}$ \\
Tambak 3 & 1.33 & 1.89 & $\begin{array}{c}\text { Oligosaprobik mobik } \\
\beta \text {-Mesosaprobik menuju } \\
\text { Oligosaprobik }\end{array}$ \\
Tambak 4 & 1.28 & 2.47 & $\begin{array}{c}\text {-Mesosaprobik menuju } \\
\text { Oligosaprobik }\end{array}$ \\
\hline
\end{tabular}


Berdasarkan Tabel 7, nilai SI tertinggi terdapat pada tambak 1 yaitu 1.5, dan nilai SI terendah terdapat pada tambak 3 yaitu 1.28. Nilai TSI tertinggi terdapat pada tambak 1 yaitu 2.50, dan nilai TSI terendah terdapat pada tambak 2 yaitu 1.89 .

\section{B. Pembahasan Struktur Komunitas}

Genera plankton yang paling banyak ditemukan adalah fitoplankton dari kelas Bacillariophyceae, menurut Nybakken (1992), jenis ini mampu tumbuh dengan cepat meskipun pada kondisi nutrien dan cahaya yang rendah. Hal ini disebabkan juga karena kelas ini mampu meregenerasi dan reproduksi yang lebih besar serta mampu beradaptasi dengan baik. Dari kelas Bacillariophyceae ini yang paling banyak ditemukan dan ada di 4 tambak adalah Coscinodiscus sp. Menurut Thomas (1997), Coscinodiscus sp., hidup di perairan laut, sel nya berbentuk simetri radial (bulat) berukuran $100 \mu$. Dinding sel nya tersusun atas silikal yang merupakan pembatas antara kerangka luat bagi sitoplasma, vakuola dan nucleus. Sel yang soliter, cangkang berbentuk segi delapan, memiliki banyak kloropas, permukaan sel berbentuk flat/datar, hidup pada temperatur optimum $25^{\circ} \mathrm{C}$ dan salinitas maksimal $36 \%$, mempunyai pola areal berbentuk radial.

Hasil analisis indeks keanekaragaman (H') di 4 tambak di Tambak Lorok Semarang yaitu tambak 1 sebesar 1.622, tambak 2 sebesar 1.893, tambak 3 sebesar 1.987 dan tambak 4 sebesar 1.715. Indeks keanekaragaman adalah suatu pernyataan atau penggambaran secara matematik yang melukiskan struktur komunitas dan dapat mempermudah dalam menganalisa informasi tentang jumlah dan macam organisme. Kriteria dalam indeks keanekaragaman adalah $\mathrm{H}^{\prime}<1=$ Keanekaragaman rendah, $1<\mathrm{H}^{\prime}<3=$ Keanekaragaman sedang, $\mathrm{H}^{\prime}>3=$

Keanekaragaman tinggi. Berdasarkan kriteria, ke 4 tambak di Tambak Lorok Semarang termasuk perairan yang memiliki keanekaragaman sedang karena memiliki nilai $1<\mathrm{H}^{\prime}<3$. Menurut Fatimah (2014), tingkat keanekaragaman suatu habitat menunjukkan tingkat kesuburan habitat tersebut. Kesuburan suatu habitat sangat mempengaruhi keanekaragaman biota di suatu komunitas.

Hasil analisis indeks keseragaman (e) di 4 tambak di Tambak Lorok Semarang yaitu tambak 1 sebesar 0.905, tambak 2 sebesar 0.972, tambak 3 sebesar 0.828 dan tambak 4 sebesar 0.824 . berdasarkan kriteria, ke 4 tambak tersebut memiliki nilai $\mathrm{E}>0.5$, yang berarti perairan tambak tersebut memiliki keseragaman yang tinggi dengan komunitas stabil. Lalu hasil analisis indeks Dominasi (C) memiliki nilai rata-rata yaitu tambak 1 sebesar 0.227 , tambak 2 sebesar 0.160, tambak 3 sebesar 0.161 dan tambak 4 sebesar 0.244 . Berdasarkan kriteria, ke 4 tambak tersebut memiliki nilai $0 \leq \mathrm{C} \leq 0.30$, yang berarti perairan tambak tersebut memiliki dominasi genera yang rendah. Semakin kecil keseragaman dalam suatu komunitas artinya bahwa penyebaran individu setiap spesies atau genera tidak merata dan ada kecenderungan suatu komunitas akan didominasi oleh spesies atau genera tertentu (Odum, 1998).

Berdasarkan hasil kelimpahan fitoplankton dan zooplankton, dapat dilihat perbandingan fitoplankton dan zooplankton dari 4 tambak yang dilakukan penelitian. Pada tambak 1, memiliki perbandingan 47:0, yang berarti tidak ada perbandingan karena tidak ditemukan zooplankton di tambak 1, pada tambak 2, memiliki perbandingan 7:1, pada tambak 3 memiliki perbandingan 17:1, dan pada tambak 4 memiliki perbandingan 7:1. Dari nilai perbandingan tersebut, fitoplankton memiliki nilai yang lebih tinggi. Menurut Nybakken (1992), siklus pembelahan sel pada fitoplankton relatif lebih singkat daripada zooplankton sehingga untuk mencapai jumlah yang banyak bagi zooplankton diperlukan waktu yang lama. Perairan yang baik adalah yang memiliki fitoplankton dan zooplankton yang seimbang. Pada tambak 1, tidak ditemukan zooplankton, hal ini mungkin akan menyebabkan ketidakseimbangan di tambak 1, karena dengan tidak adanya zooplankton, maka tidak akan ada yang mengontrol pertumbuhan fitoplankton, sehingga berpotensi memicu eutrofikasi di tambak 1, mengingat bahwa zooplankton mengkonsumsi fitoplankton. Ketidakberadaan zooplankton di tambak 1 disebabkan karena pada saat dilakukan sampling, di tambak 1 sedang terjadi pemanenan oleh petani tambak, sehingga secara tidak langsung hal tersebut berpengaruh terhadap keberadaan zooplankton di tambak 1. Selain itu dari hasil uji nitrit didapatkan hasil rata-rata $0.0935 \mathrm{mg} / \mathrm{l}$ pada tambak 1 , nilai tersebut jauh di atas baku mutu perairan untuk nitrit yaitu $0.06 \mathrm{mg} / \mathrm{l}$. Pada tambak 2, 3 dan 4 ditemukan keberadaan zooplankton, sehingga keberadaan fitoplankton masih dapat terkontrol dengan baik.

\section{Saprobitas}

Berdasarkan hasil yang diperoleh dari 4 tambak di Tambak Lorok Semarang, nilai SI dan TSI di tambak 1 yaitu 1,50 dan 2,50 yang berarti termasuk kategori Oligosaprobik atau pencemaran ringan atau belum tercemar. Hal ini disebabkan karena pada tambak 1 tidak ditemukan organisme dalam golongan Polisaprobik dan banyaknya organisme yang ditemukan dalam golongan Oligosaprobik dan non saprobik. Menurut Utomo (2013), suatu perairan dengan nilai SI dan TSI 1,5 sampai 2,0 tergolong ke dalam kelompok Oligosaprobik.

Nilai SI dan TSI di tambak 2, 3 dan 4 yaitu 1,33 dan 1,89, 1,28 dan 2,47, 1,33 dan 2,39. Ke 3 tambak tersebut termasuk ke dalam kategori Oligosaprobik atau perairan belum tercemar sampai tercemar ringan menuju $\beta$ Mesosaprobik atau perairan tercemar ringan sampai tercemar sedang. Hal ini disebabkan karena pada tambak 2, 3 dan 4 tidak ditemukan organisme golongan Polisaprobik dan banyaknya organisme yang ditemukan dalam golongan $\beta$ Mesosaprobik dan non saprobik. Hal ini diperkuat menurut penelitian Sagala (2010), indeks saprobik SI dan TSI di muara berkisar 1,09 dan 1,60, dan menurut penelitian Sagala (2011), indeks saprobik SI dan TSI di 
laut berkisar 1.17 dan 1.5. Berdasarkan 2 penelitian tersebut, nilai SI dan TSI di muara dan laut memiliki status saprobik Oligosaprobik menuju $\beta$-Mesosaprobik. Adanya perbedaan nilai SI dan TSI dari 4 tambak tersebut disebabkan bedanya perlakuan petani tambak terhadap tambaknya, karena mungkin ke 4 tambak tersebut dimiliki oleh orang yang berbeda-beda sehingga perlakuan dan perawatannya juga berbeda. Perlakuan dan perawatan tambak dapat berupa pergantian air, pemberian pakan, pengapuran dan lainnya yang dapat memberikan pengaruh terhadap kondisi air di tambak. Menurut Ritonga et al. (2014), Adanya perbedaan nilai saprobitas pada setiap daerah dipengaruhi oleh sifat fisik dan kimia perairan yang akan berpengaruh terhadap organisme saprobik baik langsung maupun tidak langsung.

\section{Parameter Fisika - Kimia Perairan}

Parameter fisika dan kimia berpengaruh terhadap kelimpahan, keanekaragaman, keseragaman, dominasi plankton baik fitoplankton maupun zooplankton dan saprobitas pada daerah tersebut. Kedalaman pada lokasi penelitian berkisar antara 43-69 $\mathrm{cm}$, kecerahan perairan berkisar antara 18-28 cm. Kedalaman dan kecerahan perairan akan mempengaruhi penetrasi sinar matahari ke dalam perairan. Menurut Nybakken (1992), Makin tinggi kecerahan, intensitas cahaya matahari yang masuk ke dalam perairan akan makin besar.

Suhu mempunyai peranan penting dalam metabolisme bagi organisme perairan termasuk fitoplankton dan zooplankton. Suhu tambak di Tambak Lorok Semarang berkisar 30-31 ${ }^{\circ}$ C. Menurut Hutabarat dan Evans (2012), suhu air rata-rata berkisar antara $24-32^{\circ} \mathrm{C}$ sehingga pada kisaran tersebut plankton dapat tumbuh dan berkembang dengan baik. Berdasarkan pernyataan tersebut, suhu di tambak termasuk ke dalam suhu yang optimal bagi fitoplankton dan zooplankton.

Arus merupakan faktor utama yang membatasi penyebaran organisme di suatu perairan. Arus di lokasi penelitian memiliki nilai $0 \mathrm{~m} / \mathrm{s}$. Hal ini disebabkan karena tambak merupakan perairan tertutup yang tidak dialiri air secara langsung. Arus di tambak dapat diperoleh dari proses pasang surut air laut, pergantian air melalui inlet/outlet yang ada di tambak, dari pergerakan kultivan yang dibudidayakan, dan yang paling utama dari pergerakan angin. Menurut Barus (2001), pada ekosistem lentik arus dipengaruhi oleh kekuatan angin, semakin kuat tiupan angin akan menyebabkan arus semakin kuat dan semakin dalam mempengaruhi lapisan air.

Oksigen terlarut (DO) di lokasi penelitian memiliki nilai berkisar 4-5.5 mg/l. DO memiliki fungsi utama sebagai respirasi organisme di perairan, selain itu memiliki fungsi lain untuk metabolisme dan oksidasi bahan bahan organik dan anorganik dalam proses aerobik. Menurut Wardoyo (1982) kehidupan ikan dan kebanyakan organisme perairan lainnya masih dapat hidup dengan layak jika kandungan oksigen terlarut perairan lebih besar dari $3 \mathrm{mg} / \mathrm{l}$. Berdasarkan pernyataan tersebut, nilai DO di lokasi penelitian masih layak bagi kehidupan organisme air disana, baik kultivan yang dibudidayakan maupun fitoplankton dan zooplankton.

Derajat keasaman $(\mathrm{pH})$ sangat berpengaruh pada adaptasi organisme perairan, $\mathrm{pH}$ dipengaruhi oleh suhu, aktivitas fotosintesis dan terdapatnya ion. Nilai $\mathrm{pH}$ di lokasi penelitian berkisar antara 7-8. Menurut Barus (2001), kisaran $\mathrm{pH}$ yang ideal untuk kehidupan organisme perairan adalah antara 7.5-8. Dari pernyataan tersebut, $\mathrm{pH}$ di lokasi penelitian masih dalam kisaran yang baik untuk organisme perairan. Salinitas berpengaruh terhadap kehidupan organisme. Salinitas dipengaruhi oleh suhu dan banyaknya air tawar atau air asin yang masuk ke badan air. Nilai salinitas di lokasi penelitian berkisar antara 25-27. Menurut Wardoyo (1982), salinitas yang optimal untuk perairan adalah antara 0.5-35\%. Dari pernyataan tersebut dapat diketahui bahwa salinitas di lokasi penelitian masih dalam kondisi baik bagi organisme perairan yang ada disana.

Nitrat dan nitrit merupakan bagian dari nitrogen yang merupakan senyawa penting bagi penyedia unsur hara bagi fitoplankton dan untuk metabolisme. Selama jumlah nitrat dan nitrit dapat terkontrol di suatu perairan, maka perairan tersebut akan dalam kondisi yang baik. Nilai nitrat di lokasi penelitian berkisar antara $0.6-0.75$ $\mathrm{mg} / \mathrm{l}$. Menurut Wardoyo (1982), kandungan nitrat yang optimum bagi pertumbuhan fitoplankton adalah 0.9-3.5 $\mathrm{mg} / \mathrm{l}$. Berdasarkan pernyataan tersebut, nilai nitrat di lokasi penelitian di bawah batas optimum. Hal ini disebabkan karena jenis tambak tersebut termasuk tambak tradisional, sehingga kualitas air nya tidak begitu dikontrol dengan baik. Rendahnya nitrat di tambak tersebut akan menyebabkan rendahnya pertumbuhan fitoplankton, dengan rendahnya fitoplankton, maka jumlah zooplankton di tambak tersebut juga akan rendah. Menurut Wickstead (1965) dalam Piranti (2013), Nutrien secara tidak langsung dibutuhkan zooplankton. Fitoplankton menggunakan nitrat untuk perkembangannya. Perkembangan fitoplankton akan mempengaruhi pula perkembangan zooplankton, hal ini dikarenakan fitoplankton adalah makanan utama bagi zooplankton.

Nitrit merupakan bentuk peralihan antara amonia dan nitrat dan antara nitrat dengan gas hidrogen, oleh karena itu nitrit bersifat tidak stabil dengan keberadaan oksigen. Pada dasarnya nitrit sendiri bersifat racun karena dapat bereaksi dengan hemoglobin dalam darah sehingga darah tidak dapat mengangkut oksigen. Manfaat nitrit sendiri bagi perairan adalah nitrit bahan dasar dari nitrat dimana nitrit akan cepat dioksidasi menjadi nitrat. Nilai nitrit di lokasi penelitian berkisar antara 0.02-0.09 mg/l. Menurut Wardoyo (1982), kadar nitrit yang lebih dari $0.06 \mathrm{mg} / \mathrm{l}$ bersifat toksik bagi organisme perairan. Berdasarkan pernyataan tersebut, tambak 1 dan 2 memiliki nilai nitrit $0.0935 \mathrm{mg} / \mathrm{l}$ dan $0.0736 \mathrm{mg} / \mathrm{l}$, keduanya memiliki nilai nitrit di atas $0.06 \mathrm{mg} / \mathrm{l}$. Hal ini disebabkan karena pada saat dilakukan pengambilan sampel, tambak 1 dan 2 sedang dalam pemanenan kultivan. Petani tambak masuk ke air, sehingga memungkinkan menyebabkan sedimen di bawah air terangkat ke atas, dimana sedimen merupakan tumpukan dari bahan organik maupun anorganik yang mengendap. Menurut Hutagalung dan Razak (1997), Penguraian bahan organik oleh mikroorganisme memerlukan oksigen dalam 
jumlah yang banyak, oksigen tersebut berasal dari oksigen bebas, namun bila oksigen tersebut tidak cukup maka oksigen tersebut diambil dari senyawa nitrat yang pada akhirnya senyawa nitrat berubah menjadi senyawa nitrit.

\section{KESIMPULAN}

Kesimpulan yang diperoleh dari penelitian ini adalah sebagai berikut:

1. Kelimpahan fitoplankton dan zooplankton di tambak 1 adalah $47 \mathrm{ind} / 1$ dan 0 ind/l, di tambak 2 adalah 49 ind/l dan 7 ind/l, di tambak 3 adalah 154 ind/l dan 9 ind/l, dan di tambak 4 adalah 58 ind/l dan 8 ind/l.

2. Perbandingan fitoplankton dan zooplankton di tambak 1 adalah 47:0 atau tidak ada perbandingan, perbandingan fitoplankton dan zooplankton di tambak 2 adalah 7:1, perbandingan fitoplankton dan zooplankton di tambak 3 adalah 17:1, dan perbandingan fitoplankton dan zooplankton di tambak 4 adalah $7: 1$.

3. Nilai SI dan TSI di tambak 1 adalah 1.50 dan 2.50, nilai SI dan TSI di tambak 2 adalah 1.33 dan 1.89 , nilai SI dan TSI di tambak 3 adalah 1.28 dan 2.47, dan nilai SI dan TSI di tambak 4 adalah 1.33 dan 2.39. Dilihat dari SI dan TSI, tambak di Tambak Lorok termasuk ke dalam perairan Oligosaprobik atau perairan belum tercemar sampai tercemar ringan dan sebagian besar dalam status $\beta$-Mesosaprobik atau tercemar ringan sampai sedang.

\section{UCAPAN TERIMA KASIH}

Penulis mengucapkan terima kasih kepada Dr. Ir. Pujiono Wahyu Purnomo, MS, Ir. Siti Rudiyanti, M.Si, Dr. Ir. Bambang Sulardiono, M.Si dan Wiwiet Teguh Taufani, S.Pi, M.Si yang telah memberikan arahan, bimbingan, kritik dan saran dalam penulisan ini.

\section{DAFTAR PUSTAKA}

Anggoro, S. 1988. Analisa Tropic-Saprobik (Trosap) Untuk Menilai Kelayakan Lokasi Budidaya Laut. Universitas Diponegoro: Semarang.

Barus. 2001. Pengantar Limnologi. Swadaya Cipta: Jakarta.

Faiqoh, E. 2015. Variasi Geografik Kelimpahan Zooplankton di Perairan Terganggu, Kepulauan Seribu, Indonesia. Journal of Marine and Aquatic Sciences, 1:19-22.

Fatimah, G. 2014. Makalah Ekologi Hewan "Keragaman dan Kekayaan Jenis”. Universitas Negeri Padang: Padang.

Hutabarat, S dan S.M. Evans. 2012. Pengantar Oceanografi. Universitas Indonesia: Depok.

Hutagalung, H. P. dan Razak. 1997. Metode Analisis Air Laut, Sedimen dan Biota. P3O-LIPI: Jakarta.

Mustafa, A., E. Ratnawati dan I. Sapo. 2010. Penentuan Faktor Pengelolaan Tambak yang Mempengaruhi Produktivitas Tambak Kabupaten Mamuju, Propinsi Sulawesi Barat. Balai Riset Perikanan Budidaya Air Payau: Makassar.

Nybakken, J.W. 1992. Biologi Laut Suatu Pendekatan Ekologis. Gramedia: Jakarta.

Odum, E. P. 1998. Dasar-Dasar Ekologi. Terjemahan Tjahjono Samingan. Edisi Ketiga. Gajah Mada University Press: Yogyakarta.

Piranti, A.S. 2013. Plankton Sebagai Pakan Alami Ikan. Universitas Soedirman: Purwokerto.

Republik Indonesia. 2004. Undang-Undang No. 31 Tahun 2004 tentang Perikanan. Sekretariat Negara: Jakarta. Ritonga, C.O M., S. Rudiyanti dan A. Suryanto. 2014. Tingkat Pencemaran di Waduk Pluit Jakarta Utara Ditinjau dari Aspek Fisika Kimia dan Indeks Saprobitas [Skripsi]. Universitas Diponegoro: Semarang.

Sagala, Effendi, P. 2010. Indeks Saprobik Komunitas Dalam Menentukan Tingkat Pencemaran Di Perairan Laut Antara Muara Sungai Benu Dan Pulau Betet, Kabupaten Banyuasin, Propinsi Sumatera Selatan. Maspari Journal, 02:11-18.

2011. Indeks Keanekaragaman dan Saprobik Plankton Dalam Menilai Kualitas Air Sungai Lematang, Di Desa Tanjung Muning, Kecamtan Gunung Megang Kabupaten Muara Enim. Universitas Sriwijaya: Palembang.

. Indeks Saprobik Komunitas dalam Menentukan Tingkat Pencemaran di Perairan

Laut antara Muara Sungai Benu dan Pulau Betet, Kabupaten Banyuasin, Propinsi Sumatera Selatan. Maspari Journal, 4(1):22-32.

2012. Komparasi Indeks Keanekaragaman dan Indeks Saprobik Plankton Untuk Menilai

Kualitas Perairan Danau Toba Propinsi Sumatera Utara. Universitas Sriwijaya: Palembang.

Suprobo, H.D., S. Anggoro dan P. Soedarsono. 2013. Penilaian Pencemaran Perairan di Polder Tawang Semarang Ditinjau dari Aspek Saprobitas. Journal of Management of Aquatic Resources, 2(3):109-118.

Utomo, Y. 2013. Saprobitas Perairan Sungai Juwana Berdasarkan Bioindikator Plankton. Universitas Negeri Semarang: Semarang.

Wardoyo, S.T.H. 1982 Pengelolaan Kualitas Air Pusat Studi Pengelolaan Sumberdaya Lingkungan. Institut Pertanian Bogor: Bogor.

Zulnaidi. 2007. Metode Penelitian. Universitas Sumatera Utara: Medan. 